\title{
Forage resources and animals' feeding in southern groudnut bassin and eastern regions of Senegal
}

\author{
El Hadji TRAORÉ ${ }^{1 *}$, Séga NDAO ${ }^{2}$, Papa Amadou Moctar GAYE ${ }^{3}$, Fafa SOW ${ }^{4}$, \\ Gualbert Séraphin DOREGO ${ }^{5}$, Cheikh Alassane FALL ${ }^{6}$ and Abdou NDIAYE ${ }^{5}$
}

\author{
${ }^{I}$ ISRA-Laboratoire National de l'Elevage et de Recherches Vétérinaires, Sénégal. \\ ${ }^{2}$ ISRA-Centre de recherche Zootechnique de Kolda, Sénégal. \\ ${ }^{3}$ ISRA-Centre de Recherches Agricoles de Saint-Louis. \\ ${ }^{4}$ ISRA-Centre de recherche Zootechnique de Dahra, Sénégal. \\ ${ }^{5}$ ISRA-Centre National de Recherches Agronomiques, Sénégal. \\ ${ }^{6}$ ISRA-Laboratoire National de Recherche sur les Productions Végétales, Sénégal. \\ ${ }^{*}$ Corresponding author ; E-mail : elhadji.traore@isra.sn / elhtra@yahoo.fr
}

\section{ACKNOWLEDGEMENTS}

This work was carried out within the framework of Plant Genetic Resources Management, founded by the National Fund for Agricultural and Agrifood Research (FNRAA) of Senegal, to whom we send our sincere thanks.

\author{
Received: 18-08-2020 Accepted: 29-09-2021 $\quad$ Published: 30-10-2021
}

\begin{abstract}
Rainfall disturbances, a consequence of the effects of climate change, aggravated by anthropogenic pressure on vegetation, are leading to the progressive disappearance of several adapted local plant species in the so-called "groundnut basin" and eastern Senegal. Also, the clearing of land for agriculture potentiates and amplifies this degradation. At this rate, the loss of most of the local plant, forage and forest resources will follow. As part of a multi-species census and collection of plant genetic resources for food and agriculture, an inventory of available forage resources in the groundnut basin and eastern Senegal was made. This inventory was made by field observations triangulated with interview data. The results show that the methods and level of exploitation of natural forage resources and crop residues differ from one area to another. The natural rangeland, which still constitutes the essential part of domestic ruminants feed in these regions, is in continuous degradation. In fact, this rangeland in groundnut basin is not very diversified like southern area, with a low index of quality and volume of pastures. Crop residues are abundant but not very varied. They represent an interest for the breeders of this zone and their sale prices can sometimes exceed those of the harvested products. This is a snapshot of the situation, valid for a given time. This situation is dynamic and can change significantly from one moment to the next. Nevertheless, the results obtained will make it possible to conceive methods of conservation and production of the identified species; in order to identify the best methods of management and sustainable use.
\end{abstract}

(c) 2021 International Formulae Group. All rights reserved.

Keywords: fodder resources, southern and eastern regions of Senegal, ligneous and herbaceous plants, crop residues. 


\section{INTRODUCTION}

Successive droughts consequences, potentiated by anthropogenic activities and the climate change effects, has resulted in a progressive disappearance of several local plant species adapted to the climatic conditions and useful for the social and economic ecosystem of our countryside (CILSS, 2005; CSE, 2005). Such a rate of disappearance, if not stopped, might result in the loss of most of our local cereals, fodder and forest plant resources. This deterioration in rainfall has had consequences on harvests and on the availability in time and space of the forage resource exploited by transhumant livestock, which has reinforced the vulnerability of local socio-ecosystems (Fall, 2014; Niang et al., 2014; Fall, 2017). In order to contribute to the preservation of this plant biodiversity, useful for food and agriculture, a collect and identifcation of local cereal species, vegetables, proteagenous and fodder plant species have been undertaken in Senegal (Fall et al, 2005). These activities were carried out to the south of the $400 \mathrm{~mm}$ rainfall pattern from the normal dry rainfall from 1971-2000, in the regions, Tambacounda, Kaffrine, Kaolack and Kédougu, as part of the implementation of the Sustainable Plant genetic Resources Management project for food and agriculture (PGRFA) financed by the National Fund for Agricultural and Agrifood Research (FNRAA).

Of course, the cultivation of fodder species is not a common practice in Senegal, and more particularly, at the level of the area visited, but the activities of multi-specific census and collection of plant genetic resources for food and agriculture devote a space to it as plant food genetic resources. The importance of fodder resources in the improvement and development of animal husbandry, including the national development contribution (more than $7 \%$ of gross domestic product and almost $35.5 \%$ of the primary sector) and in the income of farmers (farmers and breeders) is considerable. That is why it was decided that a specific summary should be devoted to the study of fodder, because the collection strategy in the field and in the granary chosen to study plant genetic resources for food and agriculture, reduced some little impact of this category of resources that are fodder species. Also, the rational use of natural grass and woody fodder and crop residues can prevent accelerated degradation of local natural resources and improve the resilience of pastoralists in the face of the negative effects of climate change. This study aimed at evaluating in situ the diversity of local fodder resources, their importance and use level by livestock breeders. Specific objectives were i) description of natural pastures and their use by breeders in the visited areas and; ii) find out the methods of harvesting and use of crop residues. Knowledge of such information could contribute to propose efficient and sustainable methods of participatory management of plant genetic resources used by breeders for animal feed.

\section{MATERIALS AND METHODS Intervention sites}

The departments of Kaffrine, Nioro du Rip, Kédougou, Bakel, Tambacounda, polarize the villages visited during the study (see Figure 1). The villages were chosen with the decentralized extension services collaboration concerned, namely: the Regional Directorates of Rural Development (RDRD), the Departmental Rural Development Services (DRDS), the Regional and Departmental Inspectorates of Veterinary Services (RIVS and DIVS), respectively, etc.

Following successive droughts in the area, the experiment in cowpea-fodder cultivation was attempted at the start of the 1970. However, the productions were mainly used to feed draft animals (horses, work oxen and donkeys) used in harnessed agriculture. Livestock (cattle, sheep and goats), fed mainly on the natural range, therefore suffered greatly from these droughts.

The producers met, recognize that the culture of fodder is not a practice rooted in habits, but the current difficulties in finding feed for animals, demonstrate its relevance. This is how the program to promote cowpeaforage production in the region, initiated by the Livestock Support Project (PAPEL), met with 
the support of farmers. The practice of fodder reserve (harvesting and conservation of bush straw) is common in the region. We must seek to improve this practice.

Sites in the Kédougou and Tambacounda regions

The area of eastern Senegal, consisting of the regions of Kédougou and Tambacounda, is the largest in Senegal and extends between isohyets 600 and $1200 \mathrm{~mm}$. Dry forest and wooded savannah cover the hills; the large valleys are invaded by gallery forest, except on the wet sandy-clay soils of the alluvial plains, which are the domain of grassy savannah (Atlas du Sénégal). Natural herbaceous and ligneous pasture is most abundant in the southeast, but is over-exploited or simply destroyed by frequent bush fires. (Table 1). In fact, the region receives a large number of transhumant herds of cattle and small ruminants from the northern regions of Senegal each year. Despite this pressure, fodder cultivation is not a common practice in the region, as is the cultivation of fodder reserves, although some herders are beginning to engage in this practice. Over the past twenty years, peanuts, cotton, bananas, and rice have been developed. Millet is still the staple cereal, widely consumed in the bush. This agricultural development provides important crop residues for animal feed.

Sites in the Kaffrine and Kaolack regions

The regions of Kaffrine and Kaolack cover the area commonly known as the "southern groundnut basin. The climate is Sudano-Sahelian with high temperatures from April to July $\left(35^{\circ}-40^{\circ} \mathrm{c}\right)$. The region is characterized by a long dry season of 8 to 9 months (November to June/July) and a short rainy season of 3 to 4 months (June/July to October). The average rainfall is around 800 to $900 \mathrm{~mm}$ per year. The relief of the region is essentially flat with three types of soils: leached ferruginous tropical soils, hydro morphic soils and halomorphic soils. The vegetation is varied and includes a shrubby savannah in the north and a more or less wooded savannah towards the south and southeast. It is an essentially agricultural zone, its inhabitants are more agro-pastoralists than farmers. However, due to the increase in cultivated areas, there has been a decrease in pastoral space, leading to the conservation and use of harvest residues (groundnut and cowpea stalks, millet and corn stalks, etc.) to feed draught animals and to run fattening workshops.

\section{Data collection}

The information was obtained during working sessions held with officials of the Veterinary Services, regional and departmental inspectors, in order to have a general description of the situation of cattle's feeding in the areas. These data were complemented by those taken during the semi-structured interviews (SSI) carried out with breeders. The questionnaire included:

i) nutritional situation of animals in the site;

ii) use of crop residues for animal feed;

iii) forage reserve practices or or not;

iv) practice (or not) of pruning of ligneous lives for forage;

v) main herbaceous and ligneous fodder species growing in the grazing area.

In order to improve the quality of the investigation data, the conclusions of the regional workshops on the promotion of fodder crops held in the above-mentioned regions are also used. In addition, extension service managers, development projects and NGOs points of view were taken into account. These were: the National Agency for Agricultural and Rural Advice (ANCAR), an extension service, the Development Corporation and textile fibers of Senegal (SODEFITEX), the Sustainable and participatory management project for traditional and alternative energies (PROGEDE) and Veterinarians without borders (VSF, 2003). 


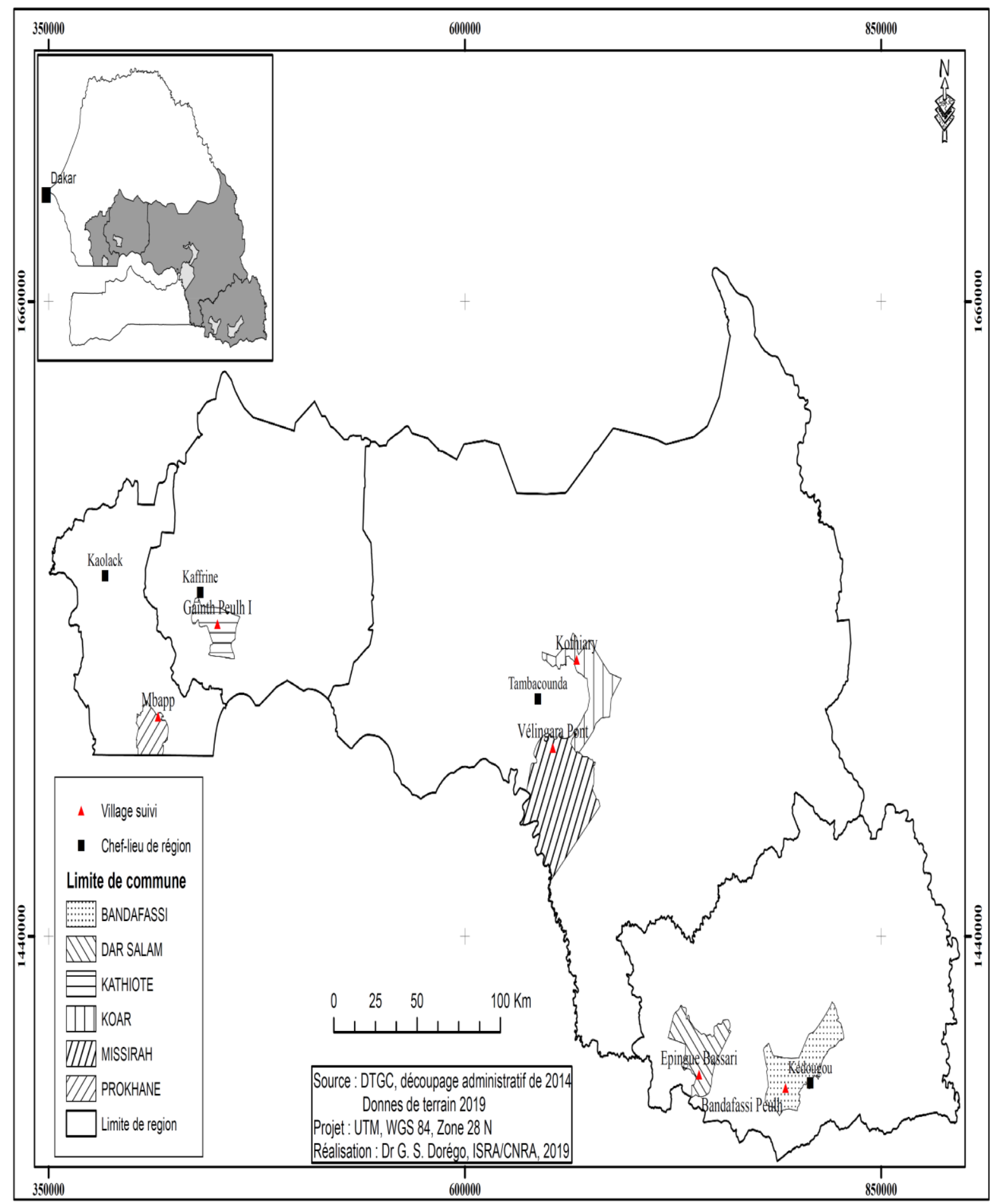

Figure 1: Representation of the villages visited in the study sites map. 
Table 1: Status of fodder in the villages visited in the eastern Senegal area.

\begin{tabular}{|c|c|c|c|c|c|}
\hline \multirow[t]{2}{*}{ Department } & \multirow{2}{*}{$\begin{array}{l}\text { Rural } \\
\text { Communities }\end{array}$} & \multirow[t]{2}{*}{ Villages } & \multicolumn{3}{|l|}{ Forage status } \\
\hline & & & Herbaceous & Ligneous & Crops residues \\
\hline Kédougou & Bandafassi & $\begin{array}{l}\text { Epingué- } \\
\text { Bassari } \\
\text { Bandafassi }\end{array}$ & $\begin{array}{l}\text { Andropogon, } \\
\text { Chasmopodium, } \\
\text { Pennisetum, } \\
\text { Digitaria, } \\
\text { Panicum, } \\
\text { Aeschynomene, } \\
\text { Imperata, Oryza, } \\
\text { Acalypha, }\end{array}$ & $\begin{array}{l}\text { Oxytenathera } \\
\text { Cissus } \\
\text { Matragyna, } \\
\text { Hyparrhenia, } \\
\text { Baissea, Ficus } \\
\text { Pterocarpus, } \\
\text { Acacia, Khaya } \\
\text { Bombax (not } \\
\text { Pruning } \\
\text { practice) }\end{array}$ & $\begin{array}{l}\text { Peanut haulm and rice } \\
\text { straw are harvested } \\
\text { and stored }\end{array}$ \\
\hline Tamba & Missirah & Bidjan Koto & $\begin{array}{l}\text { Pennisetum, } \\
\text { Digitaria, } \\
\text { Panicum, } \\
\text { Adropogon }\end{array}$ & $\begin{array}{l}\text { Ptercarpus, } \\
\text { Acacia, Khaya } \\
\text { (Pruning } \\
\text { practice) }\end{array}$ & $\begin{array}{lr}\text { Peanut } & \text { haulm, } \\
\text { sorghum stalk and } \\
\text { preserved rice } & \text { straw. } \\
\text { Cowpea } & \text { forage } \\
\text { cultivation } & \end{array}$ \\
\hline Bakel & Kothiary & Kothiaty & $\begin{array}{l}\text { Pennisetum, } \\
\text { Digitaria, } \\
\text { Panicum, }\end{array}$ & $\begin{array}{l}\text { Ptercarpus, } \\
\text { Acacia, Khaya } \\
\text { (Pruning } \\
\text { practice) }\end{array}$ & $\begin{array}{l}\text { Preserved cowpea and } \\
\text { peanut haulm. Rice } \\
\text { straw consumed in the } \\
\text { fields }\end{array}$ \\
\hline
\end{tabular}

\section{RESULTS}

\section{Sites of the regions of Kédougou and} Tambacounda

The area of eastern Senegal, which includes the regions of Kédougou and Tambacounda, is the largest in Senegal and extends between the 600 and $1,200 \mathrm{~mm}$ isohyets. Natural herbaceous (Andropogon, Chasmopodium, Pennisetum, Digitaria, Panicum) and ligneous pasture (Oxytenathera, Matragyna, Hyparrhenia, Baissea, Ficus, Pterocarpus, Acacia, Khaya) is especially abundant in the South-East, but it is overexploited or simply destroyed by the frequent bush fires in the region (Table 1). In fact, the region receives each year a large number of transhumant herds of cattle and small ruminants coming from the northern regions of Senegal. Despite this pressure, the cultivation of fodder is not a common practice and that of fodder reserves is not also a widespread activity, even some breeders are starting to devote themselves to it.

In addition, the region shelters structures of supervision and NGOs which intervene in the field of livestock breeding and which tried to encourage the practice of the culture and fodder reserve. SODEFITEX through its associative structure "Bamtaare" has embarked on the promotion of forage crops 
since 1986. Thus, housing programs for cattle traction, haymaking and silage for the feeding of draft animals have been insiders. The promotion of cowpea foraging has mainly occupied the various structures interested in the development of livestock. For example, PROGEDE has also carried out an experiment with producers on cowpeas foraging under rain. Besides the production of fodder, the methods of bundling and conservation are also taught.

\section{Kaffrine and Kaolack Regions Sites}

Kaffrine and Kaolack regions cover the area commonly known as the "southern peanut basin". It is essentially an agricultural area between the $550 \mathrm{~mm}$ and $800 \mathrm{~mm}$ rain pattern. Its inhabitants are much more agro-pastoralists than farmers. However, due to the cultivated areas extension there has been a decrease in pastoral space, leading to conservation and enhancement of crop residues (peanut, cowpea haulm, millet stalk, corn, etc.) for feeding draft animals and/or conducting fattening lot.
Because of successive droughts in the area, the experiment of cowpea-fodder cultivation was attempted at the early 1970. However, the productions were mainly used to feed draft animals (horses, oxen of line and donkeys) used in harnessed agriculture. Livestock (cattle, sheep and goats), fed mainly on the natural range, therefore suffered greatly from these droughts.

The producers met, recognize that the culture of fodder is not a local adopted practice , but the current difficulty of animals feeding, demonstrates the relevance of the fodder cropping. As a strategy, the program of cowpea-fodder production, initiated by the Livestock Support Project (PAPEL) developed in these regions were supported by the farmers. The practice of fodder reserve (harvesting and conservation of bush straw) is common in the region and must be improved. Table 2 gives the few species that are palatable on natural pasture composed with herbaceous (Anthostema, pennisetum, Dactyloctenium) and ligneous (Adansonia, Pterocarpus, Sterculia).

Table 2: Status of fodder in the villages visited in peanut basin area.

\begin{tabular}{llllll}
\hline Department & Rurales & Villages & Forage status & & \\
\cline { 3 - 5 } & communities & & Herbaceous & Ligneous & Crops residues \\
\hline Kaffrine & Kathiotte & Guinth Peul & Anthostema, & Adansonia, & Forage reserve \\
& & pennisetum, & Pterocarpus, & practice, conservation \\
& & Dactyloctenium & Sterculia & of peanut haulm and \\
& & & (Pruning & corn stalks \\
& & & practice $)$ & \\
\hline Nioro du rip & Paoskoto & Mbapp & Anthostema, & Adansonia, & Forage reserve \\
& & Dactyloctenium & Pterocarpus, & practice, peanut fading \\
& & & Ficus (Pruning & conservation \\
& & & practice $)$ & \\
\hline
\end{tabular}




\section{DISCUSSION}

A difference in fodder potential between the two study areas was noted. In fact, at the sites visited in Tambacounda and Kédougou, where rainfall is much better, there is much more natural pasture than in the groundnut basin. In Tambacounda area, which is considered a cotton zone and where animal traction is developed, crop residues are better treated. This is not the case in Kédougou sites, where there are large areas of grazing land on the hillsides that are often unsuitable for agricultural activities, and which are thus used to feed ruminant herds raised extensively. Crop residues are often left in the field (Traoré et al., 2016; Camara, 2013). However, there has been a growing interest in harvesting and preserving crop residues for sale in large urban areas. Also, in this area of eastern Senegal, the ligneous pasture composed of Oxytenathera, Matragyna, Hyparrhenia, Baissea, Ficus, Pterocarpus, Acacia, Khaya,... is well developed and diversified. It is especially appetizing at the end of the dry season and, with the early arrival of the rains, the herbaceous cover composed essentially of Andropogon, Chasmopodium, Pennisetum, Digitaria, Panicum, etc., is quickly established; this means that ligneous plants are not pruned as much as in the south of the country (Traoré et al., 2020); compared to the situation in the groundnut basin and in the north of Senegal, ligneous plants are therefore subject to less aggression.

The groundnut basin is inhabited by agropastoralists, who make good use of crop residues to feed their animals, particularly draught animals (horses, cattle and donkeys). These residues are made up of cereal straws (millet, sorghum and maize) which are very often completely harvested and used to repair fences but, increasingly, to feed the animals. They are also made up of legume leaves (cowpeas and especially groundnuts), whose selling prices in the lean season for animal feed are much higher than those of harvested products (groundnut and cowpea grain). It should also be noted that these haulms have essentially been transferred to urban areas such as Dakar, Kaolack and Touba, where urban and peri-urban farmers offer better prices. Lawal (2019) notes the same phenomenon in Niger, where the city of Niamey receives a large share of crop residues from neighboring regions. This activity, which thrives in several large West African cities, is profitable as reported by several authors (Aboh, 1999; Kiema et al. 2012; Sanou et al. 2011; Sanou et al. 2016). In this zone, the herbaceous cover mainly composed of Anthostema, pennisetum, Dactyloctenium is poor and is established later compared to the south of the country (Traoré et al., 2020) and the eastern Senegal zone. For this reason, ligneous pasture (Adansonia, Pterocarpus, Sterculia), which is less diversified than in the south and east of the country, is heavily pruned, especially at the end of the dry season, since it is the only source of fodder on the rangeland at that time.

The surveys also revealed that cowpea is the main forage crop grown by agropastoralists in the Tambacounda region. Nevertheless, herders find it difficult to grow fodder crops to feed large herds. However, as in the Kolda and Ziguinchor regions, there is a significant potential for natural fodder, the management of which must be improved. Some of the species found on the rangelands (Tables 1 and 2) are becoming rare or endangered, so there is a need to make an exhaustive inventory of natural forage species and, if possible, to restore them and develop good management methods.

ISRA has been conducting research on fodder since 1978. In addition to cowpea, the Institute has conducted research on other fodder species such as grasses, legumes and woody plants. Thus, several forage species (Stylosanthes, Brachiaria, Panicum, etc.) are listed, their bromatology and their cultivation itinerary known. Nevertheless, an effort of popularization is needed.

\section{Conclusion}

The study carried out proves the importance of fodder resources in these regions However, the methods and level of exploitation of natural fodder resources and crop residues differ from one area to another. The natural pasture routes, which are well supplied in the 
south and eastern regions, constitute the main feed resource for .. Crop residues, although abundant and varied, are of little interest to breeders in southern Senegal where the diversity or quality index and the volume of pastures on the natural range are abundant. For the northern part of these regions as well as in the agro-pastoral zones of the Kaffrine and Kaolack regions, crop residues are regularly collected and preserved for animal feed, following the observation of the harmful effects of climate change on pastures. Forage crops are still not a major concern of cattle breeders, even if some of them are interested after having benefited from NGOs advices or during the agro-pastoral development projects implementation. The lack of rainfall noted in the recent years and the lack of rigorous management of pasture routes, mean that we are seeing the beginning of the scarcity or even disappearance of certain species. This is why, at certain times of the year, trees are pruned by breeders to feed their animals. This practice must be supervised for the sustainability of the resource. The practice of fodder cultivation and the practice of fodder reserve should be a sustainable and lasting response. Also, research should focus on the selection and / or creation of fodder's varieties with multiple use (food and feed and domestic uses) which are more accepted by agro-pastoralists. To allow good management of pastures and their preservation as natural resources in the face of of climate change effects, two actions must be implemented:

- encourage the practice of fodder reserves, consisting of crop residues and herbs harvested from the natural pasture ;

- supervise pruning practices and the use of aerial fodder.

\section{COMPETING INTERESTS}

The authors declare that they have no competing interests.

\section{AUTHORS' CONTRIBUTIONS}

All the authors participated in this study and in the manuscript preparation. They all read and approved the manuscript before submission.

\section{ACKNOWLEDGMENTS}

The authors thank everyone who participated in this study.

\section{REFERENCES}

Aboh BA. 1999. La commercialisation de fourrages verts au marché de Zongo à Cotonou : état des lieux et contraintes. Bulletin Recherches Agronomiques, 25 : 8. http://www.slire.net/download/1170/abo h_bra_025_1999.

Atlas du Sénégal 1983. Sous la direction de Paul Pélissier Professeur à l'Université de Paris X-Natirerre et sous le patronage de Georges Laclavère Ancien Directeur de l'Institut Géographique Nationale avec la collaboration de Cheikh Ba et al. (2éme édition). Éd. Jeune Afrique.

Camara M. 2013. Etude du disponible alimentaire pour le bétail dans le Sénégal Oriental et le Haut Bassin du Fleuve Sénégal : Kidira-Bakel-Matam. Mém Master Dévelop Rural et cooperation, UFR des Sciences Economiques Et de Gestion/UGB, 54P.

CILSS. 2005. Changement climatique et désertification. Revue Sécheresse, synthèse $n^{\circ} 4: 95.11$

CSE. 2005. Rapport sur l'état de l'environnement au Sénégal, édition 2005. Min de l'Environnement et de la Protection de la Nature. 228 p.

FALL A. 2014. Le Ferlo sénégalais : Approche géographique de la vulnérabilité des anthroposystèmes sahéliens. Thèse de l'Université Paris-Sorbonne (Paris XIII), $380 \mathrm{p}$.

Fall A. 2017. Du Ferlo au Bassin arachidier (Sénégal) : analyse de la composition floristique de la végétation envisagée comme ressource et comme indicatrice des changements socioenvironnementaux. Physio-Géo, 11(1): 65-91.

Fall CA, Traoré EH, Ndiaye A, Fofana A, Guèye M, Fall AA, Diouf M, Guèye T, 
Niang M. 2005. Collecte multispécifiques des ressources génétiques locales dans la moitié Sud du Sénégal. Rapport de mission. ISRA-URCI, FNRAA (SEN). $60 \mathrm{p}$.

FALL ST. 1993. Valeur nutritive des fourrages ligneux. Leur rôle dans la complémentation des fourrages pauvres des milieux tropicaux. Thèse Doct. Univ. Sci. \& Techn. Languedoc, ENSAM Montpellier France. 143 p.

Kiema A, Sawadogo I, Ouédraogo T, Nianogo AJ. 2012. Stratégies d'exploitation du fourrage par les éleveurs de la zone sahélienne du Burkina Faso. Int. J. Biol. Chem. Sci., 6(4): 1492-1505. DOI: http://dx.doi.org/10.4314/ijbcs.v6i4.8

Niang K, Ndiaye O, Diallo A, Guisse A. 2014 Flore et structure de la végétation ligneuse le long de la Grande Muraille Verte au Ferlo, nord Sénégal. Journal of Applied Biosciences, 79: 6938-6946. DOI: 10.4314/jab.v79i1.15

Sanou KF, Nacro S, Ouédraogo M, Ouédraogo S, Kaboré-Zoungrana C. 2011. La commercialisation de fourrages en zone urbaine de Bobo-Dioulasso (Burkina Faso) : pratiques marchandes et rentabilité économique. Cah. Agric., 20(6): $\quad 487-493 . \quad$ DOI: 10.1684/agr.2011.0530.

Sanou KF, Ouédraogo S, Nacro S, Ouédraogo M, Kaboré-Zoungrana C. 2016. Durabilité de l'offre et valeur nutritive des fourrages commercialisés en zone urbaine de Bobo-Dioulasso, Burkina Faso. Cah. Agric., 25: 15002. DOI: 10.1051/cagri/2016007.

Traore EH, Camara M, Ngom S, Sall C, Mbaye Boye C, Diarra AR. 2016. Note on available feed for livestock in eastern Senegal and upper Senegal river basin. Int. J. Adv. Res., 4(8) : 2123-2128.

Traoré EH. 1998. Facteurs de variation de la composition chimique et de la digestibilité des ligneux consommés par les ruminants domestiques au Sahel. Thèse Doctorat 3ème Cycle ès Science. Univ. C. A Diop Dakar, 95 p.

Vétérinaires Sans Frontières (VSF). 2003. Rapport annuel d'activité, Kolda. 6 p. 